\title{
The Application of Group Investigation (GI) Method to Improve the Students' Interpersonal Intelligence in Social Sciences Learning
}

\author{
Fauzia Umami Shidiq ${ }^{1}$, Sapriya ${ }^{2}$, Eded Tarmedi ${ }^{3}$ \\ Social Studies Education Program, Faculty of Social Sciences Education \\ Universitas Pendidikan Indonesia, Bandung, Indonesia
}

\begin{abstract}
This background of this research was the lack of the students' interpersonal intelligence of Class VIII-A at SMP Negeri 14 Bandung during the learning of social sciences, marked by several students experiencing difficulties to socialize with their peers and tend to homogenicly choose their groupmates in order to form a group consisting of only their close friends. The Social Sciences' course teachers then applied Group Investigation (GI) method to improve the students' interpersonal intelligence during the teaching of Social Sciences. Interpersonal intelligence is gravely needed by students in Social Sciences learning, because individuals with excellent interpersonal intelligence level area able to communicate well and not having any trouble in establishing relationships with others. Based on the observation's result, this research was conducted to further acknowledge how was the students of VIIIA's interpersonal intelligence during Social Sciences learning process through application of Group Investigation method (GI). The research method used was descriptive qualitative with a data processing system which was suitable with the observation's results during the application of Group Investigation (GI) method in Social Sciences in class VIII-A. The research results obtained showed that the application of Group Investigation (GI) method conducted by the teachers through topics selection by groups, planning, plan execution or action, analysis and evaluation, group presentations and evaluations in Social Sciences learning indicated changes in the students' interpersonal intelligence in terms of communication and cooperation. That being said, a conclusion that the application of Group Investigation (GI) method in Social Sciences learning can inprove the students' interpersonal intelligence.
\end{abstract}

Keywords: Interpersonal Intelligence, Group Investigation (GI), and Learning.

Correspondence. fauziaumami10@gmail.com

Article History. Received January 2020, Received in revised April 2020, Accepted June 2020

C2020. International Journal Pedagogy of Social Studies. Department of Social Studies Education

\section{A. INTRODUCTION}

In social sciences learning, a learning pattern that is capable to support the achievement of the learning goals is needed. The teachers' abilities and skills in choosing and using various models, methods, and learning strategies are always improved so that Social Sciences learning may truly be able to condition the efforts to prepare the students' basic abilities and skills in order to become good human beings and citizens. The focus of the learning is not limited in the efforts to embed the students with several concepts of sheer memorization, but lies in the efforts to enable them to transform what they have learned as a provision in understanding and to play a part in living the life in their society, and as a provision for themselves to continue their education to a higher level.

The learning of Social Sciences covers the aspects of character development, social skills and cooperation which have to be well implemented within every learning processes in schools. Reckoning that one of the most vital things which needs to be strived for in conducting 
education in the $21^{\text {st }}$ century is developing the ability to cooperate, acordingly resulting interpersonal intelligence to be more focused in order to improve cooperation in learning in classes.

The early observation was done by the researcher to observe Social Sciences teachers in applying Group Investigation (GI) method in class VIII-A in Social Sciences learning. The social sciences teachers contended that class VIII-A has a different character than the other classes. Therefore, Group Investigation (GI) method was applied as one of the creative learning methods to attract the interest to learn and improve the students of class VIII-A's interpersonal intelligence in Social Sciences learning process.

Issues regarding the application of Group Investigation (GI) method in Social Sciences Learning which showed the lack of the students of class VIII-A's interpersonal intelligence were indicated by a) the lack of sense of appreciation among peers in class, due to not paying attention when others were presenting materials before the class; b) some students were difficult when taken to socialize with the others; c) some students tend to individually work on their assignments; and d) in heterogenic group distribution, some students were found difficult to accept members who were not close peers, which affected their performance.

With the presence of such issues, the researcher conducted a research on the Social Sciences teachers of class VIII-A regarding the efforts done through the application of Group Investigation (GI) method as one of the learning methods which can improve the students' interpersonal intelligence. Other than that, this research was conducted to further acknowledge regarding the application of Group Investigation (GI) method which was done by the Social Sciences teachers in order to train the students to be able to express their ideas through discoveries. Through the investigation process, the students were able to do many interactions with their peers, and train the students to improve cooperation in groups during the learning process.

Based on the explanation above, the researcher was interested to conduct a research on "The Application of Group Investigation (GI) Method to Improve the Students' Interpersonal Intelligence in Social Sciences Learning”.

\section{B. LITERATURE REVIEW}

\section{Social Sciences Learning}

Muhammad Numan Somantri (2001, pg. 92) stated that Social Sciences Education in schools (Primary and Secondary) is an integration of various disciplines of Social Sciences and Humaities, and organized basic human activities, delivered scientifically and pedagogically for educational purposes. National Council for Social Studies (NCSS) in Savage and Armstrong (1996), defined social studies as follows:

"Social studies is the integrated study of the social sciences and humanities to promote civic competence. Within the shcool program, social studies provides coordinated, systematic study drawing upon such disciplines as anthropology, archeology, economics, geography, history, law, philosophy, political sciences, psycology, religion, and siciology, as well as appropriate content from the humanities, mathematics, and natural sciences." (p.9)

Based on that definition, Social Sciences can be interpreted as an integrated study of social sciences and to develop citizenship potentials. Social Sciences Education for schools is delivered by integrating several science disciplines intended for educational purposes. Through Social Sciences education in schools, students are expected to be able to develop good citizens' abilities in order to be able to solve issues around them.

1. Skills dimensions (skills)
a) Research skills
b) Thinking skills
c) Social participation skills 
d) Communication skills

2. Value and attitudes dimensions (value and attitudes)

According to Sapriya (2009, p. 48)

Social Sciences comprehensive education program is the program which covers four dementions including:

1. Knowledge dimension (knowledge)

2. Skills dimension (skills)

a) Research skills

b) Thinking skills

c) Social participation skills

d) Communication skills

3. Action dimension (action)

Therefore, Social Sciences learning in schools is an integrated subject of several social sciences and humanities and focuses on the students' skills to become good citizens with knowledge, values, attitude, and skills.

\section{Interpersonal Intelligence}

Gadner (as cited in Safaria, 2005, p. 23) stated that interpersonal intelligence is an individual's ability to understand mood, feeling, others' desire and how to react properly.

Hajebi, et al. (2018) stated that:

"Characteristics of an Interpersonally Intelligent Student is to be leaders among peers, encourages togetherness for a feeling of belonging, "street smart"; has a high degree of common sense, has many friends in a variety of social groups, hates to study or work alone would rather do things collectively, possesses a high degree of social skills and shows concern for others." (p. 50)

The definition above emphasizes that the characteristic of interpersonally intelligent students is equal to the ability to lead their peers, to encourage togetherness, to get along with peers, to have a high level of common sense, to have numbers of friends from different social circles, to prefer collectivity in doing something, to have high social skills and to show concern for others.

Uno \& Kuadrat (as cited in Pasaribu, 2018, p.3) stated that interpersonal intelligent is also related to the ability to establish close relationships with peers, and that also includes some skills such as leading, organizing, mediating conflicts or disputes between peers, gaining sympathy from other students, etc. Interpersonal intellectual individuals would have the ability to perceive and capture differences in others' mood, goals, motivation, and feelings. Thus, the dimensions of interpersonal intelligent consist of:

1. Social Sensitivity

The ability to sense and observe the reactions or the changes of others that are shown both verbally and non-verbally.

2. Social Insight

The ability to comprehend and to solve a problem effectively in one social interaction, so that the problem would not hinder or even destroy the social relations that has been established.

3. Social Communication

The ability to communicate in establishing and building a warm interpersonal relationship.

Other indicators of interpersonal intelligence of the students is that they are able to interact with each other, to get more of the social relationships, to work in team, to take responsibilities, and to solve problems. Interpersonal intelligence could be applied in social science teaching and learning as it could develop the skill of the students in conducting an interaction, building a better life of themselves and those around them.

\section{Group Investigation Method (GI)}

Jasmine (2012, p.27) explained that to directly teach students interpersonal intelligence, it could be discussed first and then illustrated with the activities that involve:

1) Cooperative learning 
2) Group projects

3) Problem solving

4) Meeting agreements (consensus)

5) The responsibilities of school institution/organizations and the students

6) Friends and social life

7) Empathy

Therefore, the Group Investigation

(GI) method was chosen by the social science teacher of class VIII-A at SMP Negeri 14 Bandung to improve students' interpersonal intelligence. Komalasari (2015, pg75) stated that "this method involves the students ever since the planning step, both in deciding topics and the way to learn it through investigation". This method demands students to have good abilities in communication or in group process skills. Isjoni (as cited in Pramuningtyas, 2015) explained that this learning method is one of the method that stresses the ability of the students to work in groups, and also complement and help each other in understanding the subject matters taught, or finishing the assignments given.

Slavin (1995, as cited in Maesaroh, 2005, pg 29-30) described the steps of group investigation method that could be worded into:

1) Topic selection

2) Cooperation planning

3) Implementation

4) Analysis and synthesis

5) Final presentation

6) Evaluation

Mustafa, et al. (2017, p. 28) said that selecting the right material or topic according to what they desire would motivate the students to be more active in the class. Istarani (2011, p. 87-88) also stated that the advantages of group investigation method are:

a) Intergrates students with different skills through heterogenic groups.

b) Motivates the students to improve their cooperating skill.

c) Motivates the students to take responsibilities.

d) Motivates the students to discover new things. e) Motivates the students to speak up their ideas.

Meanwhile the disadvantages of group investigation method are:

a) Only some of the students could be active in discussion process.

b) It is difficult for the students to find new things.

c) The materials are incomplete.

Thus, by learning social science through the application of Group Investigation (GI) method, the students would be able to learn how to conduct an interaction, to live the life as a social creature, and to solve problems.

\section{METHOD}

This study would be using the descriptive qualitative approach. According to Moleong (2012), qualitative research is aimed to understand the phenomenon of what the research subjects experience, e.g. behavior, perception, motivation, action, etc., holistically through descriptions in a form of words, in a certain context, scientific and employs various scientific methods. The reason of the researchers using this research method is to dig a deeper meaning depicted from the facts found and occurred throughout the research process in a form of a narrative description that explains the application of Group Investigation (GI) method in order to improve students' interpersonal intelligence in social science class by the said subject teacher. This research were conducted at SMP Negeri 14 Bandung, which is located in Jalan Lapangan Supratman No. 8, Cihapit, Bandung Wetan, Bandung, Jawa Barat. The subject of the research are the 32 students of class VIII-A of SMP Negeri 14 Bandung, which consist of 12 male and 18 female students. The data collection techniques for this research involve: 1) Interview, conducted deeply to the students as the subject, and to the social science teacher of class VIII-A; 2) Observation, conducted by observing the students' behavior, the learning process inside the class, and some supporting research data namely students' attendance list, facilities and infrastructure used as the learning 
resources; 3) Documentation Study, conducted through document analysis e.g. the picture of the students activities based on the procedures that has been given by the teacher throughout the learning process. The data analysis technique applied in this research is Miles and Huberman's (as cited in Sugiyono, 2015, p. 95) model data analysis technique which consists of data reduction, display data, conclusion drawing and verification.

\section{RESULTS AND DISCUSSION}

\section{The state of interpersonal intelligence of the students in class VIII-A SMP Negeri 14 Bandung}

Most of the students of class VIII-A at SMP Negeri 14 Bandung are active, but some tend to get bored easily by the monotonous learning method. The condition of the students, then, could be depicted by the lack of interpersonal intelligence as it is shown by the lack of respect among students, the lack of communicating skill, and the tendencies of the students to choose their own group so that they could be in the same group with their close friends that they could rely on. Hence, the social science teacher attempted to change their mindset and habit in learning in order to improve their interpersonal intelligence. To do that, the teacher applied a learning method called Group Investigation (GI) as a right method to improve the student's interpersonal intelligence.

\section{Teacher's steps in applying Group Investigation (GI) method in Social Science class to improve interpersonal intelligence in class VIII-A SMPA Negeri 14 Bandung}

The application of Group Investigation method could foster the warmth of individual relationship, trust and respect for the rules, independence in learning, and respect to others' rights. In Social Science class, the teacher applied some steps to achieve a learning process that could help improving the thinking skill and the interpersonal intelligence of the students.

The stages of proficiency level can be explained as follows: Phase I of the plan is to Identify the topics and divide the students into heterogeneous groups. In this activity the teacher provides an opportunity for students to communicate with the group to choose the sub topics in which they will study and investigate. Groups are formed based on heterogeneity. Phase II of the plan is to tasks where the group leader will distribute the material to all members, in which case the teacher guides the students, especially the group leader, to be fair and show their leadership attitude, and guide the other students to accept the decisions given by the group leader. Then, the group in discuss among themselves in making a plan of the problem to be studied, how the process and learning resources are used. Phase III of the plan is to make an investigation. In this case students gather, analyze, evaluate information, and make conclusions from what they have investigated, then all group members communicate with each other about what information they each found to be compiled in one perspective to broaden the information found by the group. Phase IV of the plan is to prepare tasks. This process requires students to prepare the results of their group investigations and pour their work in the form of Project Scrapbook as instructed by the Social Studies teacher. Stage V of the plan is to present the task. All students shall present their work. and Phase VI of the plan is an evaluation where teachers and students make conclusions and reflections on all learning activities that have been carried out in class. During learning activities students also show some improvement in interpersonal intelligence as in the case that they have begun to accept the teacher's decision to divide groups heterogeneously, and the development of the process of interaction by communicating with friends in groups.

\section{Improving students' interpersonal intelligence in the application of the}




\section{Group Investigation (GI) method in Social Studies Learning can improve in class VIII-A of SMP Negeri 14 Bandung}

The application of the Group Investigation (GI) learning method to improve the interpersonal intelligence of class VIII-A students at SMP Negeri 14 Bandung has improved the students' communication and cooperation skills. Even so, not all indicators of interpersonal intelligence experience a good improvement, there are still some indicators that still need to be improved by teachers in social studies learning. The state of interpersonal intelligence of class VIII-A students supported by the opinions of Safaria (2005, pp. 24-25) in accordance with the results of field observations are:

\section{Social Sensitivity: Empathy}

The attitude of students who care about their friends is shown by the attitude of respect and help between friends in discussion activities. However, during the learning process only a few students showed that attitude of empathy.

\section{Prosocial Attitudes}

In social studies learning in class VIII-A, this attitude is shown by a number of students who are starting to be able to accept differences in group members, and able to work well together. Despite the fact that the attitude of discomfort in the group is still evident in some students.

\section{Social Insight: \\ Self-awareness}

In social studies learning in class VIII-A students', self-awareness can be categorized at the basic level, because some students are still confused in completing tasks in accordance with the division of labor that has been distributed in the groups.

\section{Understanding of social situations and social ethics}

Students begin to develop their abilities in an attitude of togetherness and cohesiveness in a team or group. It is intended from the learning process in the application of the Group Investigation (GI) method where students can unite according to the division of their group members.

\section{Problem solving skills}

In dealing with problems that must be resolved, students are only able to present the results of group discussions through investigation activities at the concept level, with the lack of comprehensiveness in their presentation.

\section{Social Communication}

The ability to communicate in grade VIII-A students in social studies learning is very good. Some students are able to express their opinions and disclaimers well and politely to their friends who are discussing in groups and speaking in front of the presentation activities, besides that students also begin to show an improvement in being a good listener and scrutinizer whilst the teacher and some students evaluate the learning process. In social studies learning with the initial character of class VIII-A students who showed a lack of interpersonal intelligence, changes in students' interpersonal intelligence can be seen from the aspects of communication and cooperation. Communication skills are very important for students because they are used as the capital to be able to interact and establish relationships with their friends, especially in class VIII-A, which in the end encourages good cooperation in a conducive learning group and creates an understanding of the social situation. Communication skills mastered by the students are being able to be good listeners, able to speak effectively, and to be able to perform public speaking. The ability to communicate is very important for students because it is used as the capital to be able to interact and build relationships with friends, especially in class VIII-A, which in the end encourages good cooperation in a learning group and creates an understanding of social situations.

\section{E. CONCLUSION}


Through the application of the Group Investigation (GI) method applied by social studies teachers in class VIII-A with steps on topic selection by groups, planning, implementing plans or actions, analysis and evaluation, group presentations, and valuations by classmates and teachers, the application of the Group Investigation (GI) method can bring an increased level of interpersonal intelligence in the ability to communicate and cooperate with students during the social studies learning process as an indicator of interpersonal intelligence. This is an achievement because the ability to communicate is very important for students because it is used as the capital to be able to interact and establish good relationships with friends which encourages the optimal cooperation process.

\section{F. ACKNOWLEDGMENT}

To the Social Studies Education Study Program, Faculty of Social Sciences Education, Universitas Pendidikan Indonesia for the publication of this article in the journal IPS Education Studies Program

\section{REFERENCES}

Istarani. (2011). Model Pembelajaran Inovatif. Medan: Media Persada.

Jasmine, Julia. (2012). Metode Mengajar Multiple Intelligences. Bandung: Nuansa Cendikia Bandung

Komalasari, Kokom. (2011). Pembelajaran Kontekstual : Konsep dan Aplikasi. Bandung : PT

Maesaroh, Siti. (2005). Efektivitas Penerapan Pembelajaran Kooperatif Dengan Metode Group Investigation Terhadap Hasil Belajar Matematika Siswa. Jakarta: Universitas Islam Negeri Syarif Hidayatullah.

Muhammad Numan Somantri. (2001). Menggagas

Pembaharuan
Pendidikan IPS. Bandung: PT. Remaja Rosda Karya

Mustofa, Ardesta Angga Adien. Dkk. (2017). Penerapan Model Group Investigation Berbantuan Media Video Untuk Meningkatkan Hasil Belajar IPS Kelas IV SD. KALAM CENDEKIA, Volume 6, Nomor 2.1. diakses dari: http://journal.uny.ac.id/index.php/hsj pi

Moleong, Lexy J. (2012) Metodologi Penelitian Kualitatif, Penerbit PT Remaja Rosdakarya

Pasaribu, Theresia Ulyana. Dkk. (2018). Hubungan Kecerdasan Intrapersonal dan Interpersonal dengan Hasil Belajar Ekonomi Peserta didik Kelas XI IPS di SMA Negeri 6 Kota Jambi. Diakses dari http://repository.unja.ac.id/4917/1/Ar tikel\%20Theresia\%20Ulyana\%20Pas aribu.pdf

Pramuningtyas, Arum. (2015). Penerapan Model Pembelajaran Group Investigation (Gi) Dengan Mind Mapping Untuk Meningkatkan Prestasi Belajar Ekonomi Peserta didik Sma Negeri 5 Surakarta Tahun Ajaran 2014/2015. Diakses dari: https://jurnal.uns.ac.id/bise/article/vie w/19928

Safaria. (2005). Interpersonal Intelligence: Metode Pengembangan Kecerdasan Interpersonal Anak. Yogyakarta : Amara Books.

Sapriya. (2009). Pendidikan IPS Konsep dan Pembelajaran. Bandung: Rosda Karya.

Sugiyono. (2015). Metode Penelitian Kuantitatif Kualitatif $R \& B$. Bandung: Aflabeta. 
FAUZIA UMAMI SHIDIQ, SAPRIYA, EDED TARMEDI/ The Application of Group Investigation (GI) Method to Improve the Students' Interpersonal Intelligence in Social Sciences Learning

16 | International Journal Pedagogy of Social Studies. Vol. 5 | No.1 | 2020 